\title{
PROBLEM SUBSTANCJI W WHITEHEADOWSKIEJ FILOZOFII PROCESU
}

\author{
METAFIZYKA BEZ SUBSTANCJI?
}

System metafizyczny, którego podstawy określił A. N. Whitehead na kartach Process and Reality, bywa często przedstawiany jako ujęcie opozycyjne w stosunku do klasycznych ujęć substancjalizmu. Wiliam Barett w swym skądinąd znakomitym opracowaniu dotyczącym ewolucji filozofii współczesnej zalicza Whiteheada, obok Heideggera, do autorów ,zjednoczonych w podejrzliwości czy nawet otwartym potępieniu pojęcia substancji" ${ }^{1}$. Kiedy w podobnych opiniach usiłuje się sprecyzować treść pojęcia „substancja” czy „,substancjalizm", pojawiają się głębokie różnice w ocenie istotnych treści filozoficznych propozycji Whiteheada. Istniejące różnice stanowisk można sprowadzić do trzech następujących typów stanowisk:

1. Metafizyka procesu zakłada definitywne odrzucenie substancjalistycznych kategorii klasycznej metafizyki oraz wprowadza radykalnie nową perspektywę poznawczą, w której pojęcia zmiany i upływu zdarzeń pełnią rolę równie podstawową jak pojęcie niezmiennych substancji.

2. Istota ujęcia Whiteheada polega na krytyce tradycyjnej teorii substancji, lecz nie na jej totalnym odrzuceniu. Niektóre elementy substancjalizmu arystotelesowskiego i kartezjańskiego muszą zostać poddane krytycznej rewizji; nie można ich jednak wyeliminować z racjonalnej interpretacji przyrody. Dlatego też uzasadniony pozostaje wniosek, iż ujęcie Whiteheada suponuje zreformowany wariant tradycyjnej doktryny substancjalizmu.

3. Mimo wyraźnej krytyki pojęcia substancji w tekstach Whiteheada, te same teksty w sposób ukryty wprowadzają odniesienia do pewnych kategorii substancjalistycznych. Sam Whitehead zdaje się pomijać milczeniem obecność wielu tez substancjalizmu w swych propozycjach filozoficznych. Fakt tej obecności stwarza jednak obiektywne podstawy do wypracowania nowej teorii substancji, która uwzględniałaby w pełniejszy sposób zarówno dane nauk przyrodniczych, jak i analityczne opracowania filozofii.

${ }^{1}$ W. B a re t t, Death of Soul, Garden City 1987, 128. 
Przedstawiciele tych istotnie zróżnicowanych stanowisk usiłują wykazywać słuszność swej interpretacji ujęcia Whiteheada przez odwołanie do odmiennych tekstów oraz wyakcentowanie dorobku z odmiennych okresów jego filozofii. Niemożliwością wydaje się jednak obrona mocnych tez pierwszego z wymienionych stanowisk. Nie można bowiem wskazać żadnego tekstu Whiteheada, w którym odrzucałby on substancję jako taką. Jego krytyka substancjalizmu koncentruje się na zakwestionowaniu uniwersalnego charakteru Arystotelesowskiej substancji pierwszej - ovbí $\pi \varrho o \tau \eta ́$. Wynikała ona nie z kategorycznej negacji filozofii Arystotelesa, lecz z przekonania, iż pojęcie statycznego substratu, istotne zarówno dla fizyki Arysottelesa jak i dla różnych nurtów materializmu, musi być zastąpione przez pojęcie przepływu energii o ściśle określonej strukturze. Stanowiska 2. i 3. mogą okazać się wzajemnie spójne, jeśli uwzględni się ewolucję poglądów samego Whiteheada.

Podstawowy problem, który chciałbym podjąć w tym artykule, dotyczy nie hermeneutyki tekstów Whiteheada, lecz merytorycznej zawartości jego metafizyki uwzględnianej z perspektywy nowych teorii przyrodniczych. W perspektywie tej nie traktuje się poszczególnych wypowiedzi Whiteheada jako ostatecznych rozstrzygnięć, lecz tylko jako elementy składowe filozoficznego programu badań, który wymaga dalszych opracowań i krytycznych rozwinięć. Ujęcie takie $\mathrm{z}$ jednej strony chroni przed dogmatyzmem interpretacyjnym. $\mathrm{Z}$ drugiej strony pozostaje ono przejawem metodyki, którą propagował sam Whitehead odwołując się do teorii fizykalnych i technik matematycznych w celu określenia ontycznej struktury świata ${ }^{2}$.

Spotykaną obecnie często opinię o antysubstancjalistycznym charakterze metafizyki procesu usiłowano uzasadniać przez uwzględnienie faktu, iż w Process and Reality Whitehead nazwał „oczywistym nonsensem” pojęcie substancji stanowiącej podłoże dla przypadłości, natomiast podmiotowo-orzecznikową strukturę zdania podstawową dla Arystotelesowskiej wersji substancjalizmu uważał on za wyraz naiwnych przednaukowych opracowań, których nie można już bronić na gruncie wspólczesnej filozofii języka ${ }^{3}$. Podstawowe obiekcje wobec ujęcia Arystotelesa były skierowane przeciw koncepcji niezdeterminowanego i statycznego substratu. Tzw. błąd statyczny (the static fallacy) polega na wprowadzeniu hipostazy niezmiennego podłoża dla zachodzących

${ }^{2} \mathrm{~W}$ artykule Mathematics and the good opublikowanym w tomie The Philosophy of Alfred North Whitehead, red. P. A. S chilp p, New York 1951, twierdzil on m. in.: ,mathematics is the most powerful of the relationship of patterns" (s. 678). W innym miejscu podkreślał on filozoficzną doniosłość teorii naukowych twierdząc, iż jego metafizyka „represents directly what physics actually does assume respecting its ultimate entities" (Science and the Modern World, New York 1925, 140; Cytowane wydanie ostatniej pracy oznaczam w dalszym ciągu tekstu skrótem SMW).

${ }^{3}$ Por. A. N. Wh it e he a d, Process and Reality, New York 1957, 92: „For Descartes the word 'substance' is the equivalent of my phrase 'actual occasion. 'I refrain from the term 'substance,' for one reason because it suggests the subject-predicate notion; and for another reason because Descartes and Locke permit their substances to undergo adventures of changing qualifications, and thereby create difficulties". W dalszym ciągu tekstu cytowane wydanie tej pracy oznaczam skrótem PR. 
w przyrodzie zmian. Whitehead kategorycznie odrzuca podobne podejście w swej wizji ewoluującej przyrody, w której nie ma miejsca dla jakichkolwiek niezmiennych obiektów. Nie kwestionuje on jednak istnienia struktur i uporządkowania w nurcie przepływających zdarzeń. Ich obecność prowadzi do podstawowej kwestii ontologicznej: Dlaczego we wszechświecie występuje porządek wyrażany w stabilności pewnych relacji nie zaś pozbawiona jakiejkolwiek koordynacji wolna gra chaotycznych parametrów?

Przy poszukiwaniu odpowiedzi na to pytanie pomocne mogą okazać się kategorie metafizyczne wypracowane przez Kartezjusza, Spinozę i Leibniza w ich teoriach substancji. Odwołując się do ich dorobku, Whitehead z zasady unika formalnego wprowadzania terminu „substancja”, najprawdopodobniej z powodu wieloznaczności terminologicznej występującej w różnych nurtach substancjalizmu. Odwołuje się on jednak wielokrotnie do substancjalistycznych tez wymienionych autorów i explicite wprowadza je do metafizycznego wyjaśnienia procesów występujących w przyrodzie. Podkreśla on wówczas, iż jego ujęcie pozostaje bliskie Arystotelesowskiej koncepcji formy substancjalnej (PR 40) zaś jego metafizyka bliższa jest Spinozjańskiej teorii substancji niż ujęciom Kartezjusza czy Newtona (PR 98).

Podobne uwagi ukazują merytoryczną bezpodstawność tych ujęć, w których usiłuje się wprowadzać łatwe opozycje między filozofią procesu a klasyczną teorią substancji. Jeżeli tej ostatniej nie utożsamia się bezpodstawnie z Arystotelesowską teorią substancji pierwszej, nie sposób kwestionować jej ukrytą obecność w zbiorze podstawowych zasad Whiteheadowskiej metafizyki procesu.

\section{FIZYKA MIKROŚWIATA A PROBLEM UNIWERSALNOŚCI POJĘCIA SUBSTANCJI PIERWSZEJ}

Opinię Williama Christiana głoszącą, iż „Whitehead usiłuje wypracować alternatywną doktrynę dotyczącą substancji" "4 krytykowano jako tendencyjną interpretację filozofii procesu. Z filozoficznego punktu widzenia znacznie bardziej doniosłe pozostaje jednak nie samo pytanie o adekwatność interpretacji metafizyki Whiteheada, lecz o wystarczalność tej metafizyki do ontologicznej interpretacji przyrody. W sceptycznej ocenie tej wystarczalności Andrew Reck utrzymuje, iż racjonalna interpretacja ciągów zdarzeń występujących w przyrodzie wymaga przyjęcia jakiejś formy substancjalizmu i akceptacji ,istnienia obiektów substancjalnych, które zachowują trwałość w procesie zmian". Zakwestionowanie istnienia takich obiektów może — zdaniem Recka - prowadzić do zakwestionowania samych podstaw filozofii procesu ${ }^{5}$.

${ }^{4}$ W. Christi a n, An Interpretation of Whitehead's Metaphysics, New Haven 1959, 111.

${ }^{5}$ A. J. R e ck, Substance, Process and Nature. „Journal of Philosophy” 55 (1958) 367. 
Najbardziej wątpliwa okazuje się wystarczalność metafizycznych kategorii Whiteheada do interpretacji specyficznie ludzkiego doświadczenia jedności osobowej. Wielu nowych komentatorów powtarza niezmiennie kwestię, którą sformułował już sam Whitehead w Adventures of Ideas pytając, jakie kategorie metafizyczne należy przyjąć „aby dostarczyć właściwego wyjaśnienia (account) tej niewątpliwej jedności osobowej, która zachowuje swą trwałość wśród różnorodnych okoliczności"? ${ }^{6}$ Arystotelesowskie pojęcie substancji pierwszej, mimo jego braków wynikających z niezgodności z kwantowomechanicznym obrazem przyrody, doskonale harmonizowało $z$ naszymi zdroworozsądkowymi intuicjami oraz tłumaczyło subiektywne odczucie tożsamości osobowej. Whiteheadowska koncepcja społeczności bytów aktualnych doskonale koresponduje $\mathrm{z}$ obrazem przyrody przyjmowanym w mechanice kwantowej, natomiast pozostaje ona zdecydowanie odległa od naszych osobistych intuicji czy doznań psychicznych. W wyniku tego wyrażane bywają wątpliwości, czy samo pojęcie tożsamości osobowej można adekwatnie wyrazić w kategoriach filozofii procesu. Podstawową kwestią pozostaje więc pytanie: Jak wytłumaczyć, po odrzuceniu Arystotelesowskiej koncepcji substancji jako biernego substratu, nasze wewnętrzne doświadczenie względnej trwałości i samotożsamości podmiotu w procesie zachodzących zmian? W systemie Whiteheada nie znajdujemy zadowalającej odpowiedzi na to pytanie. Swiadczy to tylko, iż nie wolno absolutyzować ani uważać za ostateczne ocen substancjalizmu przedkładanych obecnie w metafizyce procesu. Muszą one ulegać dalszym rozwinięciom i krytycznym opracowaniom. Ich niewątpliwą wartość stanowi natomiast krytyka niektórych uproszczeń i braków zawartych w Arystotelesowskiej koncepcji substancji pierwszej.

Mimo iż sympatycy arystotelizmu usiłują bronić uniwersalnego charakteru pojęcia substancji pierwszej, ich propozycje zdają się wyrażać wątpliwą apologetykę trudną do pogodzenia $\mathrm{z}$ wynikami fizyki kwantowej. Podstawowe dla koncepcji Arystotelesowskiej pojęcia konkretnego indywiduum, ostatecznego podmiotu czy względnej jedności rzeczy pozostają określone treściowo, gdy stosujemy je do makrozjawisk z poziomu codziennego doświadczenia. Okazują się one jednak semantycznie bezsensowne przy próbach aplikacji do mikrozjawisk. Dziedzina organizmów biologicznych i doświadczenia psychicznego może być poprawnie scharakteryzowana przy zastosowaniu kategorii filozoficznych wypracowanych w czasach Arystotelesa. Sytuacja komplikuje się jednak, gdy usiłujemy ekstrapolować pojęcie substancji pierwszej na teren mikroświata.

W analizach mechaniki kwantowej operacyjnie niedopuszczalne pozostają wypowiedzi dotyczące pojedynczych elektronów czy jednostkowych fotonów.

${ }^{6}$ A. N. Whit e he a d, Adventures of Ideas, London 1967, 187. Wydanie to w dalszym ciągu tekstu oznaczam skrótem AI. 
Filozof usiłujący bronić podobnych wypowiedzi dokonywałby nieprawomocnej ekstrapolacji na poziom mikroświata tych struktur ontologicznych, które odgrywają istotną rolę w ograniczonej dziedzinie makrodoświadczenia. Podobna ekstrapolacja mogła uchodzić za uzasadnioną w epoce Arystotelesa. Nie można jej natomiast obronić w obecnym etapie rozwoju nauki. Stąd też filozoficzna koncepcja indywidualnych przedmiotów złożonych z niezmiennego substratu i zmiennych przypadłości wydaje się stanowić antropomorfizm, gdy usiłujemy określić desygnaty wyrażenia „substancja pierwsza” na poziomie mikroświata opisując ontyczny status pól fizycznych, fluktuacji próżni, stanów wzbudzonych cząstek o czasie rozpadu rzędu $10^{-20}$ sek, etc.

Niewątpliwie przekonany arystotelik mógłby traktować zarówno „cząstki-efemerydy", jak i ich stany wzbudzone czy samo pole elektromagnetyczne jako przejawy jednej, względnie niezmiennej substancji. Podejście takie, jednak, ani nie wyrażałoby tez istotnych dla arystotelizmu, ani też - co ważniejsze - nie posiadało żadnych walorów eksplanacyjnych. Stanowiłoby ono jedynie wyraz ontologicznego związania z tradycją filozoficzną, w której subiektywne sympatie terminologiczne są cenione wyżej niż obiektywna przydatność przyjętych terminów w filozoficznej interpretacji przyrody. Arystotelesowska wizja podległego zmianom substratu pozostaje konceptualnie odległa w stosunku do tych propozycji współczesnej kosmologii kwantowej, w których fundamentalną rolę odgrywa pojęcie relacji formalnych opisywanych przez abstrakcyjne formuły matematyki. W fizykalnych teoriach kreacji wszechświata, jakie przestawili S. Hawking, J. Hartle, A. Vilenkin czy P. Englert ${ }^{7}$, podstawową rzeczywistość stanowią opisywane w języku matematyki symetrie. Istnieją one już wówczas, gdy we wszechświecie brak jakichkolwiek cząstek fizycznych i gdy nie można skutkiem tego mówić o „substracie materialnym” w obecnym rozumieniu tego wyrażenia. Tym bardziej nie można mówić o substracie w konkretnym bycie jednostkowym, gdyż cała rzeczywistość abstrakcyjnych relacji matematycznych czy opisywanych statystycznie fluktuacji próżni stanowi pewną abstrakcyjną strukturę, w której próba wyróżniania indywidualnych „substancji” składowych byłaby jedynie przejawem naiwnego antropomorfizowania. Bardziej uzasadnione wydaje się przeto pozostawienie Arystotelesowskiego pojęcia substancji pierwszej w interpetacjach zjawisk z poziomu makrodoświadczenia oraz poszukiwanie bardziej podstawowych kategorii metafizycznych, które można by ekstrapolować uniwersalnie także na poziom mikroświata.

Podejmowane są próby obrony stanowiska Arystotelesa, w których argumentuje się, iż pojęcie substancji pierwszej ma charakter uniwersalny, gdyż stanowi ono wynik tzw. koniecznościowej analizy bytu jako takiego. W podobnych próbach pomija się jednak fakt, iż wszelkie usiłowanie apriorycznego

${ }^{7}$ Bibliografię oraz popularne omówienie tych teorii można znaleźć np. w pracy Johna Grib bin a, In Search of the Big Bang, New York 1986. 
określania koniecznych elementów struktury bytu naznaczone jest nieuniknionym piętnem dowolności wynikającej z faktu, iż nasze analizy ograniczamy do znanych typów bytu i nie zawsze jesteśmy w stanie przewidzieć możliwości istnienia bytów o odmiennej strukturze. W podejściu takim bardzo często brak wyobraźni prowadzi do absolutyzowania pewnych struktur, które uważa się za absolutnie konieczne jedynie dlatego, że nie dostrzega się możliwości alternatywnych rozwiązań. Sympatycy wspomnianego podejścia pomijają z reguły fakt, iż krytyka substancjalizmu wyprowadzana z przesłanek przyrodniczych, w tym również krytyka przedstawiona przez Whiteheada, nie rozwinęła się z powodu uprzedzeń czy niechęci do arystotelizmu, lecz z uzasadnionego merytorycznie przekonania, iż pojęcie biernego niezmiennego substratu wydawało się naturalne na gruncie preferencji lingwistycznych średniowiecznej logiki, natomiast nie można go podtrzymywać po rewolucji naukowej Einsteina-Plancka.

Zakwestionowanie uniwersalnego charakteru pojęcia substancji pierwszej nie musi jednak prowadzić do totalnej negacji tego pojęcia. Można je nadal stosować w metafizycznym wyjaśnianiu tych dziedzin, które znane były Arystotelesowi. Trudno jest również oskarżać Stagirytę, iż nie przewidział, że przyszły rozwój wiedzy doprowadzi do odkrycia struktur ontycznych radykalnie różnych od struktur z poziomu makroświata. Racjonalnie uzasadnione pozostaje natomiast poszukiwanie nowych wariantów substancjalizmu, w których unikając antropomorfizmów metafizyki Arystotelesa można zachować jej kategorie na poziomie makrodoświadczenia natomiast na poziom mikroświata zastosować nowe pojęcia o uniwersalnym charakterze. Sam Whitehead zdawal się opowiadać za taką właśnie sugestią, kiedy w zakończeniu II rozdziału IV części Process and Reality twierdził, iż „niektóre cechy fizycznego świata” można w dalszym ciągu tłumaczyć przez odwołanie do pojęcia substancji pierwszej (PR 363). Pojęcia tego nie można jednak uważać za ostateczne i uniwersalne. Dlatego też podstawową doniosłość uzyskuje kwestia: Jakie nowe pojęcia metafizyczne mogłyby odgrywać obecnie równie podstawową rolę, jaką w przyszłości przy interpretowaniu zjawisk z dziedziny makroświata odgrywało pojęcie substancji pierwszej?

\section{FORMA ZAMIAST SUBSTRATU}

Odrzucenie przez Whiteheada koncepcji substancji pierwszej wynikało z przekonania, iż koncepcja ta jest zarówno nieprzydatna jak i niemożliwa do zastosowania przy filozoficznej interpretacji nowych odkryć fizyki mikroświa$\mathrm{ta}^{8}$. Zdroworozsądkowe przeciwstawienie między biernym substratem $\mathrm{i}$ jego

${ }^{8}$ SMW 53. 
zmiennymi własnościami stwarzało interpretacyjne problemy już na gruncie mechaniki Newtonowskiej, która ukazywała przyrodę jako „ponurą sprawę, pozbawioną dźwięków, kolorów i zapachów"9. Kiedy cechy charakterystyczne przyrody opisywane przy pomocy predykatów okazały się uzależnione od naszych zmysłów w niemniejszym stopniu niż od fizycznego substratu, John Locke usiłował uważać opisywane w kategoriach ilościowych położenie i masę za istotne własności obiektów fizycznych. Rozwój fizyki odsłonił jednak nowe braki w przedstawionej przez Locke'a reinterpretacji substancji, kiedy w teorii Einsteina koncepcja przestrzeni uległa radykalnej zmianie zaś masę zaczęto traktować jako „ilość energii rozpatrywaną w odniesieniu do określonych efektów dynamicznych"10.

Kiedy pojęcia masy i materii utraciły swą podstawową rolę w fizycznym obrazie świata, Wilhelm Ostwald w swym Ûberwindung des naturwissenschaftlichen Materialismus zaproponował pojęcie energii jako centralną kategorię filozoficzną. Aczkolwiek Whitehead podzielal opinię Ostwalda, iż nowożytna fizyka definitywnie przezwyciężyła materializm epoki Oświecenia, nie sądził on, iż w nowej filozofii przyrody pojęcie energii będzie odgrywać tę samą rolę, jaką w przeszłości odgrywało pojęcie substancji. Energia była dla niego ,jedynie terminem określającym ilościowe aspekty struktury zdarzeń"11. Nowej ontologii nie można skonstruować przez proste wprowadzenie przyrodniczych terminów do słownika klasycznej metafizyki. System filozofii, w którym wykorzystuje się przełomowe odkrycia nauki, musi poddać głębokim rewizjom tradycyjne wzorce tłumaczeń, aby wypracować nowe schematy metafizyczne bardziej adekwatne od wcześniej przyjmowanych schematów. Skoro pojęcie substratu materialnego utraciło swą wcześniejszą pozycję w nauce, istnieje konie-؛ czność wypracowania nowego systemu metafizyki, w którym wprowadzone zostaną nowe tłumaczenia uwarunkowań wyjaśnianych w tradycyjnej teorii substancji pierwszej. Szczególną doniosłość uzyskuje w tej perspektywie pytanie o czynnik ontyczny warunkujący niezmienność pewnych relacji znajdujących odwzorowanie w występujących w przyrodzie ciągach zdarzeń.

Mimo powierzchownych podobieństw, metafizyka procesu pozostaje odle-

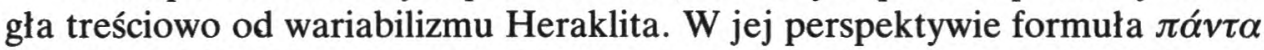
peĩ nie upoważnia do obrony ontologicznego relatywizmu, lecz dostarcza intrygujących pytań o ontyczną rację porządku odkrywanego w przepływie zdarzeń (PR 241). Heraklitejska formuła „wszystko płynie” po przekładzie na nowy język fizyki matematycznej uzyskuje postać „,wszystko ma strukturę wektorową" (PR 362). W następstwie przepływu, zanikających zdarzeń nie można traktować ani jako złudnej maya ani też jako przypadkowej gry chaosu. Ciągi zda-

\footnotetext{
9 Tamże, 55 .

10 Tamże, 96.

11 Tamże, 96.
} 
rzeń mają bogatą strukturę matematyczną, której tłumaczenie „stanowi jedno z głównych zadań metafizyki” (PR 241).

Kiedy Leibniz usiłował zmodyfikować doktrynę substancji w świetle danych XVII-wiecznej fizyki, odwoływał się on do pojęć siły czy potencjalności dynamicznej, aby przy pomocy nowych terminów wyrazić treści bliskie klasycznej metafizyce ${ }^{12}$. Podobne podejście można dostrzec u Whiteheada, gdy w odniesieniach do obiektów ponadczasowych, bytów aktualnych czy pierwotnej natury Boga implicite akceptuje on wiele tez zaliczanych do klasycznej teorii substancji. $\dot{W}$ The Interpretation of Science przyznaje on otwarcie, iż jego pojęcie mijających zaistnień (perishing events) zastępuje Kartezjańskie pojęcie trwałych substancji ${ }^{13}$. Mijające zaistnienia, zwane częściej bytami aktualnymi, stanowią minimalne jednostki konstytuujące rzeczywistość doświadczaną przez nas w kategoriach czasoprzestrzennych. Zlożone obiekty, które na poziomie makrodoświadczenia ujmujemy jako względnie trwałe całości, są strukturami konstytuowanymi przez byty aktualne, tzn. składają się ze „społeczności", tzw. ciągów lub wiązek, następujących sukcesywnie bytów aktualnych. W podobnej wizji przyrody nie ma miejsca na bierny substrat. Trzeba natomiast przyznać, iż ciągi bytów aktualnych nie stanowią przypadkowych agregatów bez określonej struktury, lecz mają ściśle określoną strukturę formalną. Poszczególne grupy bytów aktualnych nie tylko pozostają w bliskiej zależności między sobą z powodu wzajemnych współoddziaływań (prehensions), lecz również wykazują w tych współoddziaływaniach specyficzną formę znamienną dla poszczególnych grup. Ta wspólna forma, nazywana przez Whiteheada „cechą określającą” (defining characteristic) społeczności bytów aktualnych, wykazuje oczywiste analogie z Arystotelesowskim pojęciem formy substancjalnej (PR 40).

Mimo odrzucenia pojęcia substancji pierwszej, metafizyka Whiteheada przejmuje wiele elementów dziedzictwa Arystotelesa, gdyż względna trwałość i niezmienność określonych struktur ujawnia się w upływie zdarzeń, kiedy ta sama struktura formalna znajduje realizację w ciągach przemijających zdarzeń. Różnica między Arystotelesem a Whiteheadem przejawia się w tym, iż pierwszy z wymienionych myślicieli pojmował formę substancjalną jako cechę charakterystyczną bytów jednostkowych. W odróżnieniu od niego, Whitehead pojmuje „cechę określającą" jako wspólną formę ciągu bytów aktualnych. W konsekwencji, jak podkreśla Ivor Leclerc, „u Whiteheada pojawia się coś, 433.

12 G. W. Leibniz, Philosophical Papers and Letters, ed. L. E. L oe m ke r, Dordrecht 1969,

13 „In the place of Descartes's substance with 'endurance' as one of its principal attributes, we must put the notion of an 'occasion' with 'supercession' as parts of its real essence" (The Interpretation of Science, Indianapolis 1961, 240). 
co nie mogło wystąpić u Leibniza - wielość, która jest czymś więcej niż prostym agregatem" 14 .

Dzięki temu, iż w metafizyce Whiteheada ta sama struktura formalna znajduje realizację w wielości indywidualnych bytów, ujęcie takie pozostaje bliskie Arystotelesowskiej koncepcji substancji drugiej rozumianej jako istota, forma czy powszechnik. Być może obecność tej koncepcji w dorobku Arystotelesa była wynikiem wpływów Platona, który pozostaje myślicielem szczególnie bliskim Whiteheadowi. Niektóre opinie Stagiryty trudno jest uzgodnić w sposób spójny, gdyż np. w Metafizyce Z 7 (1032b 1f) abstrakcyjna istota (eîdos) jest przedstawiana nie tylko jako substancja (ovbía), lecz również jako substancja pierwsza. Zostawiając na boku kwestie hermeneutyczne dotyczące zarówno obiektywnej ewolucji myśli Stagiryty jak i zależnych od czasu jego upodobań terminologicznych, musimy zauważyć, iż w scholastycznej teorii substancji dużą rolę odgrywało pojęcie substancji drugiej, tzw. deutera ousia, dotyczące gatunkowych własności poszczególnych bytów. W swym komentarzu do Metafizyki Arystotelesa, Tomasz z Akwinu rozróżniał cztery typy substancji, aby następnie sprowadzić je do dwóch podstawowych typów - pojętego jednostkowo podmiotu oraz do rodzaju czyli formy ${ }^{15}$. Pojmowana rodzajowo substancja druga odgrywa centralną rolę w filozofii Whiteheada, mimo iż przy określaniu jej roli w ontycznej strukturze świata używane są inne terminy niż termin „substancja"16.

Wydaje się, iż w metafizyce procesu koncepcja substancji drugiej uzyskuje bardziej szczegółowe rozwinięcie, niż miała w metafizyce Arystotelesa. Kreatywny porządek przyrody nie stanowi w ujęciu Whiteheada ani przypadkowego faktu ani też zagadkowej rzeczywistości pozbawionej głębszego uzasadnienia. Dynamiczny porządek kosmosu ma swą ostateczną ontyczną podstawę na poziomie obiektów ponadczasowych stanowiących element składowy pierwotnej natury Boga (PR 58). Racjonalność i porządek przyrody uzyskuje w tej perspektywie bezpośrednie odniesienie do immanentnego Boga, który ujawnia swą immanencję przez harmonię praw natury. To Bóg w Swej pierwotnej naturze ${ }^{17}$ konstytuuje idealne struktury, jakie mogą znaleźć realizację w ewoluującej przyrodzie ${ }^{18}$. Relacje określające istotę tych struktur są opatrywane

${ }^{14}$ I. Le cle r c, The Nature of Physical Existence, New York 1972. 290. Por. też późniejszy komentarz ze s. 291.

${ }^{15} \mathrm{~S}$. Thom a e Aquinatis, In duodecim libros Metaphysicorum Aristotelis expositio, Romae 1964, 241.

${ }_{16}$ Zob. przypis 3.

17 Wyrażenie ,pierwotna natura” (primordial nature) w słowniku Whiteheada pozostaje skorelowane z określeniem „wtórna natura” (consequent nature). By uniknąć interpretacyjnych dylematów z epoki sporu z monofizytyzmem, oraz by dokładniej wyrazić istotę treści wyrażenia te czasem tlumaczy się jako „pierwotny (resp. wtórny) aspekt natury Bożej”. Zob. J. Ż y ci ń s ki, Teizm i filozofia analityczna, t. 2, Kraków 1988.

18 „Deity [...] is that factor in the universe whereby there is importance, value and ideal beyond the actual. It is by reference of the spatial immediacies to the ideals of deity that the sense of worth beyond ourselves arises. The unity of a transcendent universe, and the multiplicity of reali- 
mianem obiektów ponadczasowych (eternal objects). Ich rolę w ontycznej strukturze świata sam Whitehead porównuje do roli Platońskich form (PR 58). Mimo realnego charakteru, obiekty ponadczasowe określają jedynie dziedzinę potencjalnego rozwoju bytów aktualnych. Gdyby usiłować je rozpatrywać niezależnie od ich bytu w pierwotnej naturze Boga, nie można by ich uznać za byty realne. Ich egzemplifikacje zrealizowane w ciągach zanikających bytów aktualnych decydują o obserwowanej jedności wszechświata (oneness of the universe), w której ujawnia się zarówno determinacja przez przeszłość jak i ukierunkowanie ku przyszłym celom, jedność formy i wielość konkretnych bytów.

Mimo iż sam Whitehead nazywa swą filozofię „,dogłębnie kartezjańską" (PR 23) oraz przyznaje że pojęcie substancji jest w niej przekształcone w pojęcie bytu aktualnego (PR 237, można łatwo wskazać wiele podobieństw między Spinozjańską koncepcją substancji jako causa sui a koncepcją bytów aktualnych dzielących z Bogiem własność autokreacji (self-causation: PR 260). Zarówno ontyczna więź między bytami aktualnymi, jak i stabilność struktur odkrywane w dynamice przepływu zdarzeń odsłaniają doniosłą metafizycznie strukturę wszechświata. Ukryta rzeczywistość, która przejawia się w procesie ewolucyjnych przemian, może być porównana do „Spinozjańskiej jednej nieskończonej substancji" (SMW 159). Stanowi ono zarówno źródło dynamizmu bytów jak i rację uporządkowania ich struktur. Tym samym pozostaje ona bliska jednej substancji Spinozy, która in se est et per se concipitur ${ }^{19}$. W obu wymienionych systemach metafizyki rzeczywistość ta stanowi ostateczną ontyczną rację tłumaczącą racjonalność i porządek przyrody ${ }^{20}$.

Obecność uporządkowanych struktur w ewoluującej przyrodzie można u Whiteheada wytłumaczyć dzięki przyjęciu istnienia hierarchii relacji, które są ontycznie pierwotne w stosunku do konkretnych procesów fizycznych. Relacje te są konstytuowane przez obiekty ponadczasowe, które determinują „(możliwe) związki z wszystkimi innymi obiektami ponadczasowymi”21. Skutkiem istnienia tej właśnie relacyjnej struktury wszechświata, pierwotnej w stosunku do konkretnych zdarzeń, proces ewolucyjnych zmian w przyrodzie ,jest czymś więcej niż procesem" (MT 100). Aby wyjaśnić zachodzące aktualnie procesy, trzeba odwołać się do bardziej podstawowej rzeczywistości określającej dziedzinę potencjalnego rozwoju bytów aktualnych. Uwżględnienie jej roli w ontycznej strukturze świata sprawia, iż konkretne zdarzenia odsłaniają ukryte głębiej uwarunkowania, które konstytuują poziom harmonii form istnieją-

zed actualities, both enter into our experience by this sense of deity" (Modes of Thought, New York 1966, 102; wydanie to oznaczane jest w tekście artykułu symbolem MT).

${ }_{19}$ B. Spin oza, Ethica, I, df. 3: „Per substantiam intelligo id quod in se est et per se concipitur; hoc est, id, cujus conceptus non indiget conceptu alterius rei, a quo formari debeat".

${ }_{20}$ Por. J. B. C o b b, A Christian Natural Theology Based on the Thought of Alfred North Whitehead, Philadelphia $1965,139$.

21 „Whitehead to Hartshorne, 2 January 1936”, [w:] Alfred North Whitehead: Essays on His Philosophy, ed. G. Klin e, Englewood Cliffs 1963, 199. 
cej w potencjalnościach pozbawionych jeszcze zaktualizowania (MT 71, 99). Różnorodne przejawy tej harmonii ujawniają się w dziedzinie matematyki, estetyki czy ideałów moralnych. Sonety Szekspira i fugi Bacha, relacje formalne wyrażone w tabliczce mnożenia i moralna wzniosłość Kazania na Górze zawierają ten sam element uporządkowanych struktur, który „przenika” na różnych poziomach rzeczywistość upływających zdarzeń. Refleksja nad jego rolą w ontycznej strukturze bytu była tak ważna dla racjonalnej tradycji Zachodu, iż nie można zrozumieć istotnych treści naszej cywilizacji po zignorowaniu tej roli (MT 76-78).

Aby określić ostateczny poziom uwarunkowań ładu metafizycznego, estetycznego czy moralnego, trzeba - wzorem Spinozy - uwzględnić rolę Boga w przyrodzie. Bóg stanowi dla Whiteheada ontyczny czynnik, który wnosi w nasz świat „doniosłość, wartość oraz ideały wykraczające poza doraźny stan faktyczny" (MT 102). Istoty tego, co faktyczne nie można zrozumieć przez proste badanie obserwowalnej rzeczywistości, gdyż żadne procedury empiryczne „nie mogą ujawnić pełni potencjalności przyrody”22. Wbrew empirycznej krytyce substancjalizmu, istotę tę odkrywamy na poziomie refleksji dotyczącym obiektów ponadczasowych oraz pierwotnej natury Boga. Na tym właśnie poziomie znajdujemy ontyczne uwarunkowania rozwoju wszechświata (PR 40) i wzorce wartości (SMW 160), „podstawę racjonalności” (SMW 161) oraz „podstawę rzeczywistości konkretu” (SMW 160). Krótkotrwałe czasowo zdarzenia „powstają przez partycypację w rzeczach wiecznych” (PR 53). Obserwowany nurt efemerycznych zdarzeń ma swe ontyczne zakorzenienie w transcendentnym porządku idealnych form. Porządek ten odgrywa w metafizyce procesu podobną rolę, jaką substancja odgrywała w metafizyce Arystotelesa, Kartezjusza i Spinozy. Podczas gdy kosmos Arystotelesa stanowił zbiór indywidualnych substancji, dla których transcendentny Poruszyciel stanowił rację dynamicznych oddziaływań, wszechświat Whiteheada pozostaje zdecydowanie bliższy ujęciu, które na Areopagu przedstawił Grekom Paweł Apostoł mówiąc o Bogu, w którym „żyjemy, poruszamy się, jesteśmy” (Dz. Ap. 17, 28). Immanentny Bóg konstytuuje elementarny poziom ontycznej racjonalności świata. Rzeczywistość logosu jest ontycznie pierwotna w stosunku do indywidualnych bytów, które zarówno w swym istnieniu jak i w procesie rozwoju wy-

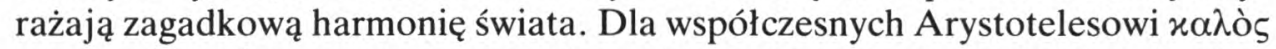

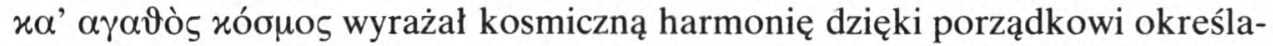
nemu przez indywidualne substancje. Dla Whiteheada i jego kontynuatorów konkretne ciągi zdarzeń mają uporządkowane struktury dzięki pierwotnej ontycznie rzeczywistości obiektów ponadczasowych, które istnieją w Bogu ,przenikającym" całą rzeczywistość stworzenia. Nie jest to Bóg wprowadzany jako deus ex machina wyłącznie do wyjaśnienia trudnych kwestii ontologii, gdyż

22 Tamże, 299. 
cały nasz byt i każda forma refleksji może istnieć i rozwijać się jedynie dzięki „zanurzeniu” w Boskim Logosie, który ujawnia swą obecność w harmonii struktur odkrywanej na różnych poziomach naszej egzystencji.

\section{WNIOSKI}

Podejmując ocenę scholastycznej teorii substancji, Descartes przeciwstawił te jej elementy, które stanowią konieczny warunek racjonalnej interpretacji świata, tezom substancjalizmu wikłającym się w wewnętrzne sprzecznoś$\mathrm{ci}^{23}$. Whitehead kontynuował tę procedurę, gdy przejmując pozytywne elementy substancjalizmu Descartesa i Spinozy poddał równoczesnej krytyce niektóre z ich szczegółowych propozycji. Ciąglość tradycji została zachowana również u wielu współczesnych krytyków Whiteheada, którzy usiłują łączyć jego obronę klasycznej metafizyki z równoczesną krytyką niejasności Whiteheadowskiego stylu i nierzadko niepotrzebnie udziwnianej terminologii. We współczesnych dyskusjach dotyczących choćby statusu obiektów ponadczasowych znajdują nadal wyraz głębokie różnice interpretacji filozoficznych wynikające m. in. z sympatii do ontologii Platona lub Arystotelesa. Inne polemiki wynikają z faktu, iż w doborze terminów filozoficznych Whitehead „był autorem dalekim od ostrożności" 24 . Mimo utrzymującej się różnicy ocen, możliwe jest sformułowanie pewnych ogólnych tez dotyczących roli substancji w metafizyce Whiteheada. Orzekają one $\mathrm{m}$. in.:

1. Filozofia procesu jest wyrazem podejścia epistemologicznego, w którym zdecydowanie odrzuca się tezy empiryzmu. Ostateczne determinanty obserwowanego porządku przyrody znajdują się na poziomie niedostępnym do bezpośredniej obserwacji. Poziom ten odkrywamy dzięki analizom ontologii. Stąd też łączenie filozoficznych propozycji Whiteheada z Heideggerowską krytyką onto-teologii wprowadza niedopuszczalne uproszczenia, w których pomija się fakt, iż pierwszy z wymienionych autorów bronił przed pozytywizmem sensowności metafizyki i uważal ją za istotny składnik naszej cywilizacji.

2. Odrzucenie przez Whiteheada Arystotelesowskiej koncepcji substancji pierwszej wynika z tego, iż koncepcja ta - przydatna w interpretacji znanych Stagirycie zjawisk biologicznych - pozostaje sztucznym antropomorfizmem w dziedzinie mikrozjawisk badanych w fizyce kwantowej. Pojęcia substancji pierwszej nie można zaliczać do uniwersalnych pojęć metafizyki, niemniej można posługiwać się nim nadal przy tłumaczeniu „niektórych cech świata fizycznego" (PR 363). Za uzasadnioną może uchodzić sugestia, iż pojęcie to można w dalszym ciągu stosować w antropologii filozoficznej, gdzie baza terminologi-

${ }^{23}$ Jako przykład tych ostatnich Kartezjusz przytaczal pojęcie substancji niezupełnej, pisząc w Reponses aux quatriémes objections I, par. 13 o wewnętrznej sprzeczności sugestii, iż mogą istnieć „des choses qui subsistent par soi, et [...] qui ne peuvent pas subsister par soi".

${ }_{24}$ J. L. N o b o, Whitehead's Metaphysics of Extension and Solidarity, Albany 1986, 1. 
czna wypracowana w filozofii procesu okazuje się wyraźnie niewystarczalna do analizy podejmowanych problemów.

3. Elementy ontologii Heraklita obecne w filozofii procesu nie implikują totalnej negacji pojęcia substancji, ponieważ upływ zdarzeń nie ma w ujęciu Whiteheada charakteru chaotycznego, lecz stanowi egzemplifikację struktur konstytuowanych przez obiekty ponadczasowe. Zasady przyjęte przez Whiteheada w celu wyjaśnienia natury tych struktur wykazują duże podobieństwo do Arystotelesowskiej teorii substancji drugiej, Kartezjańskich res verae oraz Spinozjańskiej causa sui.

4. Niechęć Whiteheada do posługiwania się pojęciem substancji mogła wynikać, przynajmniej częściowo, z pragnienia uniknięcia wieloznaczności związanych z różnymi wariantami substancjalizmu. Sam fakt, iż nadal utrzymują się kontrowersje przy próbach rekonstrukcji Arystotelesowskiej teorii substancji, skłaniał do wypracowania nowej terminologii, w której dałoby się uniknąć wcześniejszych polemik. Terminologiczne preferencje Whiteheada wyrażone np. w jego zastąpieniu Kartezjańskiej „substancji” przez „byt aktualny” pozostają relatywnie nieistotne po uwzględnieniu roli, jaką w metafizyce procesu odgrywa pojęcie struktur formalnych oraz niezaktualizowanych potencjalności.

5. Nowe teorie fizykalne, w których pojęcie substratu materialnego nie odgrywa żadnej roli, potwierdzają Whiteheadowską tezę, iż pojęcie materii zniknęło $\mathrm{z}$ naukowego obrazu świata zaś istotne struktury fizyczne można opisać w języku relacji matematycznych. Rewolucja epistemologiczna, zapoczątkowana przez odkrycia Einsteina i Plancka, trwa w dalszym ciągu niosąc teorie, które wydają się niemożliwe do pogodzenia z tradycyjną filozofią materializmu i empiryzmu. Metafizyczne implikacje tych teorii można natomiast relatywnie latwo określić na gruncie metafizyki procesu.

6. Trudne do przeprowadzenia pozostaje wykazanie, iż Whitehead uznawał „konieczność przyjęcia zreformowanej doktryny substancjalizmu” ${ }^{25}$. Znacznie łatwiej można natomiast wykazać, iż podstawowe zasady jego metafizyki pozostają bliskie założeniom przyjmowanym w tradycyjnych teoriach substancji. Krytyczna refleksja dotycząca zarówno propozycji Whiteheada jak i klasycznych wariantów teorii substancji może przyczynić się do wypracowania nowych ujęć, w których unika się zarówno Scylli naiwnego empiryzmu jak i Charybdy uproszczeń widocznych w metafizyce Arystotelesa. 


\title{
THE PROBLEM OF SUBSTANCE IN WHITEHEADIAN PROCESS METAPHYSICS
}

\author{
Sum mary
}

In debates concerning the relationship between basic principles of Whiteheadian process philosophy and the classical doctrine of substance, one can distinguish at least three types of essentially different approaches to the issue. Their substantial content may be summarized in the following way:

1. Process metaphysics implies definitive rejection of substantialist categories of traditional philosophy and introduces a radically new perspective in which notions of flux and change replace the former categories of enduring substances and relative immutability of individual sujects.

2. Whitehead's approach to the traditional doctrine of substance results in a strong critique of it but not in total rejection. Certain elements of the Aristotelian and Cartesian legacy must be critically revised, but they cannot be eliminated from rational interpretation of nature. Their implicit presence in Whiteheadian interpretative schemes substantiates the opinion that process metaphysics introduces a reformed version of the doctrine of substance.

3. In spite of explicit critique of the concept of substance found in Whitehead's texts, the same texts implicitly presuppose the necessity of reference to certain substantialist categories. Whitehead himself did not always formally recognize such a necessity; his metaphysical assertions, however, provide an objective basis for developing a modified theory of substance.

Supporters of these essentially different viewpoints try to vindicate their approach by providing references to various works of Whitehead. It seems, however, impossible to defend thesis 1 . unless general statements of „substantialist categories” are replaced by a more detailed formula concerning Aristotle's theory of primary substance. Whitehead did not deny substance in general but only the static substance of a material substratum; this denial resulted not from his critique of Aristotle but rather from a conviction that the notion of static stuff so important for philosophical materialism must be replaced by the notion of fluent and structured energy (PR 362). Theses 2 . and 3. may turn out to be mutually consistent if different texts of Whitehead are taken into consideration to justify them.

The basic issue discussed in this paper deals not with hermeneutic questions concerning consistent interpretation of various Whiteheadian texts but with the substantive content of process metaphysics approached in the context of new scientific evidence. In such an approach, Whitehead's particular pronouncements on substance are not regarded as final conclusions but only as constitutive elements of an intellectually appealing philosophical vision that needs further detailed elaborations.

The exact reconstruction of Whitehead's attitude to the traditional doctrine of substance remains difficult because of substantial evolution in his views as well as due to that fact that in choosing linguistic forms he was a far from careful writer. In spite of persisting interpretative dilemmas, an analysis of basic principles of Whiteheadian metaphysics renders groundless many popular opinions in which process philosophy is supposed to discard categorically any form of substantialism. When introducing indispensable distinctions in this simplified image, it seems particularly important to notice that:

1. Considering Whitehead together with Heidegger as authors united in their suspicion or open condemnation of substance overlooks their different attitudes towards traditional metaphysics. While Heidegger in his critique of onto-theology called into question basic assumptions of metaphysics, Whitehead regarded metaphysical reflection as an important constitutive element of human civilisation.

2. Whitehead's views on this topic should be connected with the empiricist critique of substance, because he explicitly acknowledges that metaphysical reflections upon substance and the Abso- 
lute were important for the growth of our civilization as they implied overcoming naive empiricism.

3. Definitive rejection of the Aristotelian concept of primary substance results form the fact that this notion, useful in interpreting biological phenomena known to Aristotle, remains useless anthorpomorphism in the domain of the microworld. This concept cannot be treated as universal and ultimate in metaphysics, but it still may be useful to interpret „some features of the physical world." $(P R, 363)$ This acknowledgment leaves open the question whether or not the concept can be still used in philosophical anthropology where the terminological basis provided by process metaphysics remains evidently inadequate.

4. Heraclitean elements contained in process philosophy do not imply denial of substance, because the flux of events, as interpreted by Whitehead, is not an accidental chaos but an ordered exemplification of relations constituted by eternal objects. Whiteheadian principles explaining this order, contain many thing in common with the Aristotelian theory of secondary substance, Descartes' res verae and Spinoza's causa sui.

5. Whitehead's reluctance to use the term „substance” might have been inspired, at least in part, by an attempt to avoid terminological ambiguities connected with the term. The very fact that even debates on variants of Aristotle's theory of substance still generate new controversies would definitively prompt one to introduce terminology independent of controversial issues of the past. Terminological preferences expressed in replacing Cartesian „substance” by „actual entity" remain relatively unimportant when the role of formal structure and unactualized potential is taken into consideration in the new interpretative patterns.

6. New physical theories in which the physical substratum plays no role confirm the Whiteheadian thesis that matter disappeared from the scientific image of nature and that essential physical structures can be described in the terms of mathematical relations. This epistemological revolution originated by Einstein and Planck still goes on in physics providing theories that seem hardly consistent with the philosophy of materialism and empiricism. Metaphysical ramifications of these theories can be easily interpreted in terms of process metaphysics.

7. It is hard to demonstrate conclusively that Whitehead accepted the necessity of a reformed doctrine of substance. It is much easier to discover that central principles of his philosophy remain close to metaphysical tenets underlying the doctrine of substance. Critical reflection upon both the principles and the doctrine may turn out to be heuristically valuable and can really reverse the slow descent of accepted thought towards the inactive commonplace. 